\title{
SECONDARY METABOLITES AND BIOLOGICAL PROFILES OF DATURA GENUS
}

\author{
CAMILO CÉSPEDES-MÉNDEZ ${ }^{a, c^{*}}$, PATRICIO ITURRIAGA-VÁSQUEZ ${ }^{b, c} A N D$ EMILIO HORMAZÁBAL ${ }^{b^{*}}$ \\ ${ }^{a}$ Doctorado en Ciencias de Recursos Naturales, Facultad de Ingeniería y Ciencias, Universidad de La Frontera, Temuco, Chile. \\ ${ }^{b}$ Center of Excellence in Biotechnology Research Applied to the Environment, Universidad de La Frontera, Temuco, Chile. \\ ${ }^{c}$ Laboratorio de Síntesis Orgánica y Farmacología Molecular, Departamento de Ciencias Químicas y Recursos Naturales, Facultad de Ingeniería y Ciencias, \\ Universidad de La Frontera, Temuco, Chile.
}

\begin{abstract}
Solanaceae is an important family of plants where many species of this family are source for food, industrial products, ornamental and medicinal uses. Within the family of Solanaceae, the genus Datura is one of the most interesting, in principle for its known medicinal and psychotropic uses against different pathologies. Multiple biological activities of Datura species have been documented. The species of the genus are attributed with insecticide, fungicide, antioxidant, antimicrobial, hypoglycemic, and immune response enhancing activity against cancer cells. These activities are related to the presence of different secondary metabolites such us: terpenoids, flavonoids, withanolides, tannins, phenolic compounds and tropane alkaloids, the main secondary metabolite of the genus Datura, being the most abundant atropine and scopolamine. The propose of this review is to identify the main phytochemical compounds isolated from the genus Datura and describe their biological activities associated to different secondary metabolites.
\end{abstract}

Keywords: Solanaceae, phytochemical, metabolites, pharmacological potential, Datura.

\section{INTRODUCTION}

Solanaceae is an economically important plant family in the world. They are a monophyletic group containing approximately 100 genera and 2500 species [1]. It corresponds to a cosmopolitan family of flowering plants mainly distributed in the tropical and temperate regions, such as, Australia and Central and South America [2]. The family includes species used for food (potato, tomato), industry (tobacco), ornamental (angel's trumpet), and medicinal (belladonna) [3]. Solanaceae has a wide distribution in South America [4], and produce different secondary metabolites, such as: alkaloids, steroids, steroidal saponins, phenols, terpenoids, among others [5].

The genus Datura (solanacea) has always caused interest for its phytochemical and ethnopharmacological characteristics [6]. The genus is native to North America, India, Australia, and China, however, today it is possible to find the species worldwide [7].

The genus comprises 14 species (table 1) of annual herbs and perennial shrubs from 1 to $1.5 \mathrm{~m}$ tall, with straight stems, fruits full of thorns, leaves that emit an unpleasant odor, and very aromatic trumpet-shaped flowers that are born at the fork of the stems (figure 1) [6], [8]. Plants of the genus Datura develop mainly in nitrogen-rich soils and soils disturbed by human activity such as agricultural soils, roadsides, or animal pens [9].

In America, the use of species of the genus Datura has been documented in sanatory and religious rites even by pre-Columbian peoples. Its use in North America before the arrival of the Europeans has been reported as treatment for physical injuries, and, in low doses, as an aphrodisiac and in divine rituals [10]. Since the 16th century, the use of the genus Datura has been established in traditional medicine, associated with its psychotropic, anticholinergic, analgesic, or anti-inflammatory effects, among others [9]. In Chile, Datura stramonium, or "Miyaya" called by Mapuche people, has been used as a psychiatric narcoanalysis by eating of ground seeds and under supervision of a Machi [11]. The psycho-active use of this plant is associated to narcosis and transitory delusions that produce a trance, however the mainly use of this species is as a "truth drug" where its use is the prediction of future behavior and personality, this prediction is made by the Machi [11]. Datura metel has been documented in treatments for mental disorders, fevers, tumors, or skin diseases in India [12].

Furthermore, in the Chinese tradition, it has been documented its use for treatment against pustules, anal prolapse or nervous disorders [13], [14]. In the case of Datura quercifolia, it is also attributed activities against infections, cancer treatment and rheumatoid arthritis [15].

Currently, it has been documented that different extracts of the genus Datura not only have the described narcotic effects, also cover the treatment of other pathologies (antimicrobial, anti-inflammatory or cytotoxic activities), as well as potential agricultural uses (insecticide, herbicide), among others [13], [16]-[20].
The biological activities attributable to the genus Datura are related to the wide variety of secondary metabolites present in the plant. The mainly components are steroids, phenolic compounds, fatty acids, withanolides, and lactones, although the genus is mainly known for its production of tropane type alkaloids [6], [21][23].

Based on the ethnopharmacological uses and the diversity of chemical compounds presented by the genus, the objective of this article was to identify the main phytochemical components isolated from the genus Datura and describe their activity against different diseases and pathogens, with emphasis on the relevant literature of recent years.

Table 1. Geographical distribution of species belonging to the genus Datura and location within the three sections of the genus

\begin{tabular}{|l|l|l|l|}
\hline \multirow{4}{*}{ Section } & Species & $\begin{array}{l}\text { Geographical } \\
\text { distribution }\end{array}$ & Reference \\
\hline \multirow{5}{*}{ Dutra } & Datura discolor & Mexico & {$[24]$} \\
\cline { 2 - 4 } & Datura innoxia & Mexico, Botswana & {$[25],[26]$} \\
\cline { 2 - 4 } & Datura kymatocarpa & Mexico, Spain & {$[9]$} \\
\cline { 2 - 4 } & Datura pruinosa & Mexico & {$[27]$} \\
\cline { 2 - 4 } & Datura reburra & Mexico & {$[24]$} \\
\cline { 2 - 4 } & Datura wrigthii & Australia & {$[28]$} \\
\cline { 2 - 4 } & Datura leichardtii & Australia & {$[28]$} \\
\cline { 2 - 4 } & Datura velutinosa & Cuba & {$[24]$} \\
\cline { 2 - 4 } & Datura lanosa & Mexico & {$[24]$} \\
\cline { 2 - 4 } & Datura metel & Mexico, Egypt & {$[29]$} \\
\hline Ceratocaulis & Datura ceratocaula & Mexico & {$[30]$} \\
\hline \multirow{5}{*}{ Datura } & Datura stramonium & Mexico, France & {$[31]$} \\
\cline { 2 - 4 } & Datura quercifolia & USA, Mexico & {$[32]$} \\
\cline { 2 - 4 } & Datura ferox & Botswana & {$[29],[25]$} \\
\hline
\end{tabular}

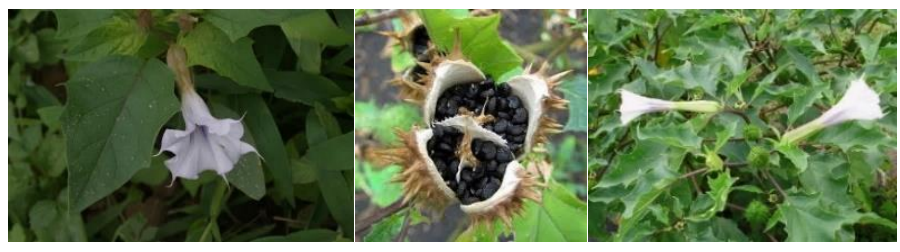

Figure 1. Some of parts of individuals of the genus Datura. From left to right: leaves and flower of Datura metel; seeds of Datura stramonium; flowers and leaves of Datura stramonium 


\section{Phytochemistry of the genus}

The biological activities attributed to the genus Datura are related to the chemical components (metabolites) presents. These compounds are produced in both primary and secondary metabolism of plants [33]. Primary metabolites are directly involved in the growth, development, and reproduction of plants, while secondary metabolites possess ecological functions [34].

In different species of the genus Datura, the presence of different groups of compounds has been described, such as terpenoids, flavonoids [35]-[37], steroids [22], [28], lectins [39]-[41] glycosides, fatty acids, saponins [12], tannins [42], phenolic compounds [12], [18], [43], withanolides [44]-[46] and different volatile terpenes [47], [48].

\section{Terpenes}

The genus Datura has different numbers and types of glandular and nonglandular trichomes and produce volatile compounds that are emits against damage caused by herbivores [49]. Seventeen volatile compounds have been identified in D. wrightii, most of them are sesquiterpenes (Figure 2), such as limonene, linalool, (E)-3,8-dimethyl-1,4,7-nonatriene (DMNT), and (E)- $\beta$ ocymene where (E)- $\beta$-caryophyllene is the most abundant volatiles [48], [49].<smiles>C=C(C)C1CC=C(C)CC1</smiles>

Limonene

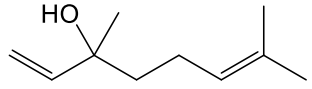

Linalool

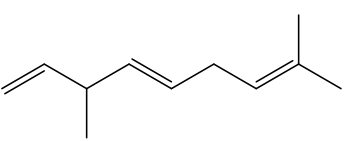

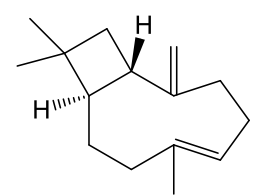

beta-Caryophyllene
(E)-3,8-dimethyl-1,4,7-nonatriene (DMNT)

Figure 2. Structure of some isolated volatile compounds (terpenes) in the genus Datura in response to insect damage

From D. metel has been described sesquiterpenes and diterpenes, where 16ß,17-dihydroxy-ent-kauran-19-oic acid, paniculoside-IV and kaurane acid glycoside A, were isolated for the first time in Solanaceae, recently. (Figure 3) [50].

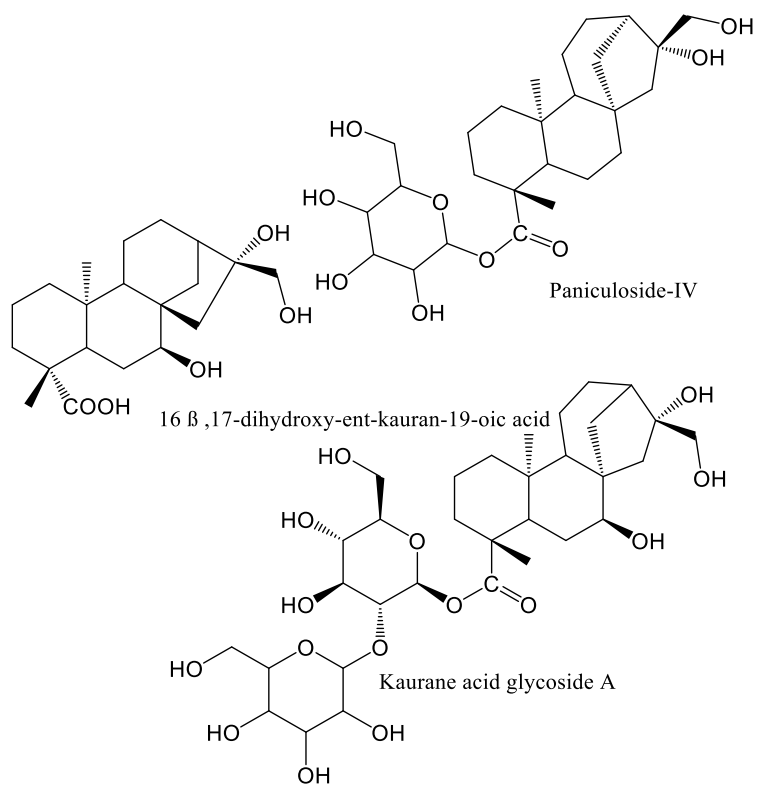

Figure 3. Structures of $D$. metel terpenes first identified in the Solanaceae family.

The identification of compounds from D. metel stems presented 6 sesquiterpenes, where two new compounds were isolated for the first time in the genus Datura (figure 4) [51]. On the other hand, nine new and three known sesquiterpenes were isolated from $D$. metel leaves displaying anti-inflammatory activity in nitric oxide production suppression assays [35].
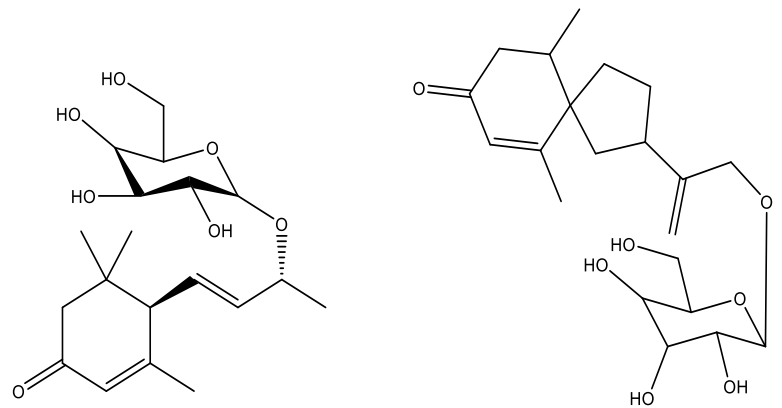

$(4 R)-3,5,5$-trimethyl-4-((3R,E)-3-(((3R,4S,6R)-3,4,5- $\quad$ 6,10-dimethyl-2-(3- $(((2 R, 3 R, 4 R, 6 R)-3,4,5-$ trihydroxy-6-(hydroxymethyl)tetrahydro- $2 H$-pyran-2- trihydroxy-6-(hydroxymethyl)tetrahydro- $2 H$-pyranyl)oxy)but-1-en-1-yl)cyclohex-2-en-1-one $\quad$ 2-yl)oxy)prop-1-en-2-yl)spiro[4.5]dec-6-en-8-one

Figure 4. First identified sesquiterpenes in D. metel stems

\section{Phenolic compounds}

The presence of different groups of phenolic compounds in the genus Datura has been documented in methanolic and hydroalcoholic extracts. D. metel and D. stramonium present flavonoids, tannins, as well as glycosidic phenolic compounds [12].

Hossain et al [43] determined the presence of phenolic compounds in D. metel in different solvent fraction such as ethyl acetate, butanol, hexane, chloroform, and methanol. Analysis of methanolic extracts of roots and leaves of D. metel showed gallic acid, vanilic acid, quercetin and ferulic acid as the major phenolic compounds [23].

On the other hand, the composition analysis of the methanolic extract of the aerial organs of $D$. innoxia performed by means of LC-ESI-MS/MS showed the presence of 20 different phenolic compounds, where (-)-Epicatechin, (+)Catechin, Hyperoside, p-Coumaric acid (Figure 4), are the most abundant metabolites isolated [52]<smiles>O=C(O)/C=C/c1ccc(O)c(C(F)(F)F)c1</smiles>

Figure 5. Structure of most abundant polyphenols identified in D. innoxia

\section{Withanolides}

Withanolides are a group of steroidal lactones that have been isolated from different genera of Solanaceae [54]. These compounds have been reported to exhibit biological activities such as anti-inflammatory, antioxidant, antitumor, insecticide, antifood, and immunosuppressive properties [53], [54]. Different withanolides have been isolated and characterized within the genus Datura (daturalactones), differentiating themselves by possessing an epoxy in the lactone ring [15].

Five withanolides were identified from the aerial parts (flowers, leaves and stems) of D. quercifolia Kunth (Figure 6) which showed weak cytotoxic and prooxidant activities, as well as a relevant inhibitory activity against acetylcholinesterase [44]. 


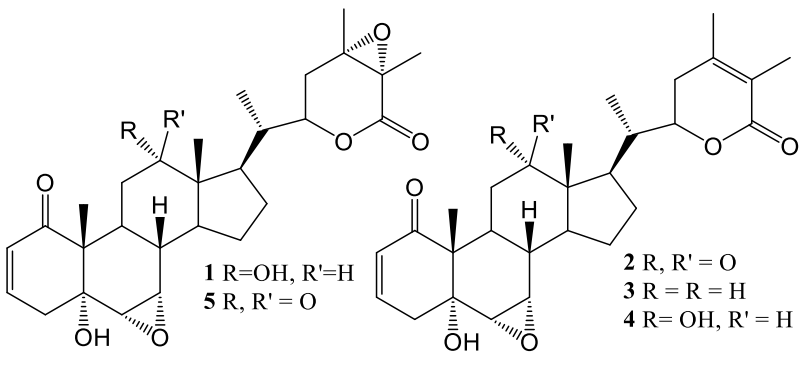

Figure 6 Withanolides active against acetylcholinesterase isolated from $D$. quercifolia

Many new undescribed withanolides were isolated from leaves of D. metel and two of them has showed anti-inflammatory activity [35].

In addition, thirteen other withanolides were isolated from flowers of D. metel and has showed immunosuppressive properties against splenocyte proliferation in mice, as well as activity against human gastric adenocarcinoma cell proliferation (SGC-7901), human hepatoma (HepG2) and human breast cancer (MCF-7) in vitro [51].

\section{Lectins}

Lectins are a group of carbohydrate-specific binding proteins that have been isolated from D. stramonium and other Solanaceaes [55]. There are controversies regarding the biological role of lectins, although a defensive role for plants has been proposed due to the toxicity of lectins in both mammals and insects [41], [56]-[59].

D. stramonium agglutinin (DSA) is a chitin-binding lectin that has been extracted and purified from $D$. stramonium seeds [60]. The use of D. stramonium agglutinin in lectin microarrays has been used in the identification of renal pathologies in diabetic patients. Results of lectin microarrays revealed that $\mathrm{N}$ acetyl-D-glucosamine (GlcNAc) linked to $(\beta-1,4)$-linked N-acetyl-Dglucosamine recognized by lectin $D$. stramonium agglutinin (DSA) was significantly higher in patients with diabetic nephropathy [50].

\section{Alkaloids}

The genus Datura shows a varied phytochemical composition of tropane-type alkaloids and correspond to the most active compounds in the plant [37], [38], [61], [63].

In particular, tropane alkaloids are a group of about 200 alkaloids with a tropane ring (N-methyl-8-azabicyclo[3.2.1.] octane) (Figure 6) in their chemical structure, where the main precursor of this group is L-ornithine [64].

The most abundant alkaloids present in the genus Datura are Atropine (hyoscyamine) and Scopolamine (hyoscine) [65], [66].

The alkaloid analysis in D. ceratocaula showed 36 compounds in the alkaloid fraction that shows a characteristic mass fragmentation spectrum, being Atropine the most abundant alkaloid in seed, and Scopolamine the most abundant in flowers [67]. Similar abundances of Atropine and scopolamine have been observed in D. ferox, reaching $0.32 \mathrm{~g}$ of scopolamine per $100 \mathrm{~g}$ of dry plant material [68], [69]. In D. innoxia the presence of Scopolamine and Atropine was observed in aerial parts, and 3a-6b-Ditigloyloxytropane and Atropine in roots [70].

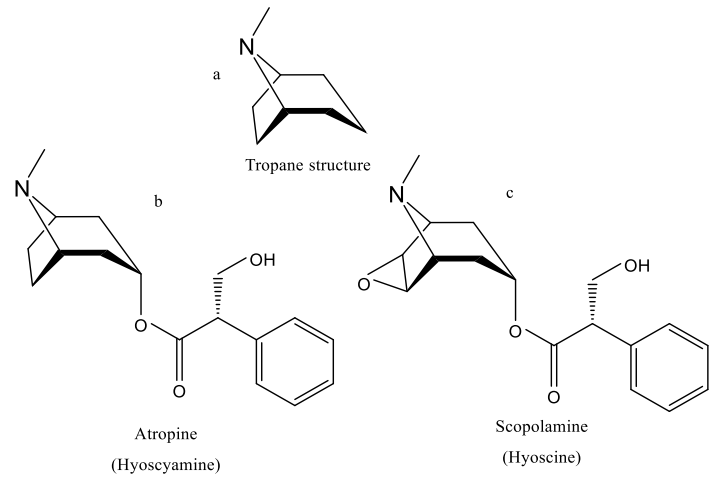

Figure 7 a) Base structure of the tropane alkaloids. b) and c) Hyoscyamine and Hyoscine, the two most abundant alkaloids present in the genus Datura

The main alkaloids were Scopolamine and Atropine, varying their concentrations depending on the part of the plant [14]. Tropinone, Tropine, Pseudotropine, Atropine, and Scopolamine are the most abundant alkaloids in $D$. quercifolia [32].

In particular, at least 67 tropane alkaloids (table 2) have been identified in different parts of the plant in the species D. stramonium [64], [65]. Of which, in addition to atropine and scopolamine, the most abundant have been identified as Tropine, 3-Tigloyloxy-6-propionyloxy-7-hydroxytropane, 3,6-Ditigloyloxy-7hydroxytropane [71].

Table 2 Most abundant tropane alkaloids identified in the genus Datura [32], [65], [71].

\begin{tabular}{|c|c|c|}
\hline Alkaloid & Specie & Organ \\
\hline Scopolamine & All & $\begin{array}{l}\text { Roots, leaves, } \\
\text { flowers, and } \\
\text { seeds }\end{array}$ \\
\hline Atropine & All & $\begin{array}{l}\text { Roots, leaves, } \\
\text { flowers, and } \\
\text { seeds }\end{array}$ \\
\hline 3-Tigloyloxy-6,7-dihydroxytropane & $\begin{array}{l}\text { Datura } \\
\text { stramonium }\end{array}$ & Roots \\
\hline Apoatropine & $\begin{array}{l}\text { Datura } \\
\text { stramonium }\end{array}$ & $\begin{array}{l}\text { Roots, leaves, } \\
\text { flowers, and } \\
\text { seeds }\end{array}$ \\
\hline 3-Tigloyloxy-6-hydroxytropane & $\begin{array}{l}\text { Datura } \\
\text { stramonium }\end{array}$ & Roots \\
\hline Hyoscyamine & $\begin{array}{l}\text { Datura } \\
\text { stramonium, } \\
\text { Datura quercifolia }\end{array}$ & $\begin{array}{l}\text { Roots, leaves, } \\
\text { flowers, and } \\
\text { seeds }\end{array}$ \\
\hline $\begin{array}{l}3 \alpha \text {-Tigloyloxy-6-isovaleroyloxy-7- } \\
\text { hydroxytropane }\end{array}$ & $\begin{array}{l}\text { Datura } \\
\text { stramonium }\end{array}$ & Roots \\
\hline 3,6-Ditigloyloxy-7-hydroxytropane & $\begin{array}{l}\text { Datura } \\
\text { stramonium }\end{array}$ & Roots \\
\hline Scopolamine & $\begin{array}{l}\text { Datura } \\
\text { stramonium }\end{array}$ & $\begin{array}{l}\text { Roots, leaves, } \\
\text { flowers, and } \\
\text { seeds }\end{array}$ \\
\hline Tropine & All & $\begin{array}{l}\text { Roots, leaves, } \\
\text { flowers, and } \\
\text { seeds }\end{array}$ \\
\hline 3-acetoxynortropane & Datura quercifolia & Roots \\
\hline
\end{tabular}

On the other hand, Okwu and Igara [72] identified one steroidal alkaloid in D.metel (figure 8 ) with significant antibacterial activity.

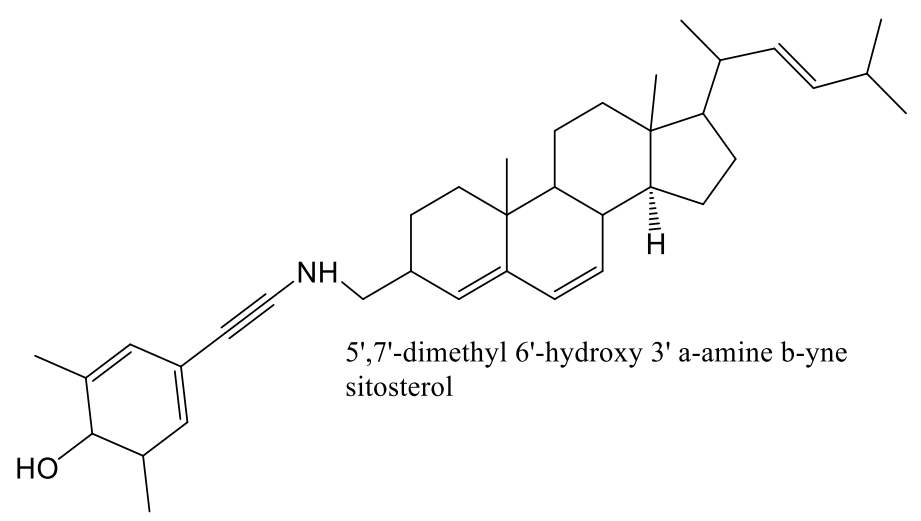

Figure 8 Alkaloid with antibiotic activity isolated by Okwu and Igara [72].

\section{Biological activities of the genus Datura}


Different biological activities in the genus Datura associated with the different metabolites described have been studied. These properties are beneficial both in

\section{Insecticide activity}

The insecticidal and repellent activity of Datura species has been addressed by different authors [5]. Leaf extracts of D. metel (acetone, water, and petroleum ether) have been documented to display insecticidal and insect repellent activity against different insect species in contact and spray application assays. $\mathrm{EC}_{50}$ results showed values of 12,000 ppm for grasshoppers and 11,600 ppm for red ants in organic extracts of D. metel [38], [61], [62], [73]. In the case of $D$. stramonium, insecticide activity has been evaluated in non-polar extracts, both by contact and by diet, in adult individuals and larvae of different insects [56], [74], [75].

The larvicidal effect of the aqueous root extract of $D$. stramonium was measured against two species of mosquitoes, reaching between $50 \%$ and $100 \%$ larval mortality at $100 \%$ concentration of the extracts at $24 \mathrm{~h}$ after the treatment was applied [76]. On the other hand, the effect of $D$. wrightii's trichome exudates against Manduca sexta larvae reached 20\% mortality [77].

Different concentrations of an aqueous extract of leaves and seeds of $D$. stramonium was presented as an effective treatment against flea beetles which is a major pest of maize [78].

The effect of acetone extracts from Datura inoxia was evaluated against Tribolium castaneum, Trogoderma granarium and Sitophilus granarius where the toxic effect of the plant extracts was observed in addition to the inhibition of enzymes acetylcholinesterase (AChE), $\alpha$-carboxylesterase $(\alpha-\mathrm{CE}), \quad \beta$ carboxylesterase ( $\beta-\mathrm{CE})$, acid phosphatases (ACP) and alkaline phosphatases (ALP) in toxicity test survivors showing lethal effects against three stored grain insect species by up to $15 \%$ lethality associated to a significant effects on $\mathrm{AChE}$ inhibition, $\alpha$-EC, $\beta$-EC, ACP and ALP at different concentrations [78].

\section{Herbicidal}

D. metel has reported potential herbicidal activity against "noxious weed parthenium" in aqueous and methanolic extracts, where the root presents outstanding effects compared to the stems, with both extracts inhibiting weed germination, as well as the development of the stems in individuals of a couple of weeks [6]. Similarly, the herbicide activity of D. metel has been evaluated against Phalaris minor where germination inhibition occurred in methanolic and hexane root extracts [79].

Sakadzo, et al. [80] reported the significative effect of aqueous extract of $D$. stramonium in inhibiting root development, plumule length, and dry matter amount against Amaranthus hybridus and Tegetes minuta with pre- and postemergence herbicidal effects.

\section{Acaricide activity}

The methanolic extracts of leaves and seeds of D. stramonium showed acaricidal effects reaching $98 \%$ mortality of adult individuals of Tetranychus urticae Koch (spider mites) in the leaf extract, and 25\% mortality for the seed extract, where a direct relationship between concentration and mortality rate was observed for the leaf extracts, without the relationship in the seed extracts [37].

Ethanolic extract from Datura stramonium leaves achieved 20\% mortality against Rhipicephalus microplus (Asian blue tick) in adult mite immersion trials [81]. Similarly, the methanolic extract of D. stramonium reached a $77 \%$ inhibition in the oviposition of Rhipicephalus (Boophilus) microplus in in vitro assays [82].

\section{Antifungal activity}

The antifungal activity has been evaluated in 3 species of the genus: $D$. discolor, D. metel and D. stramonium. Ethanolic and methanolic extracts from stems and leaves of $D$. discolor were mixed with the culture medium where, Aspergillus flavus, Aspergillus niger, Penicillium chrysogenum, Penicillium expansum, Fusarium moniliforme and Fusarium poae were grown, resulting in a significant inhibition of A. flavus growth of $66.2 \%$ and up to $60 \%$ inhibition against $P$. chrysogenum [12].

Aqueous and methanolic extracts of $D$. metel leaves had antifungal activity against Rhizoctonia solani. Methanolic extract of D. metel exhibited up to 35\% more toxicity than other 15 species studied, inhibiting mycelial growth and the agricultural field (herbicide, acaricide, insecticide) and in the medicinal field (antibacterial, cytotoxic, or antioxidant).

sclerotium production [46]. Moreover, extracts of all parts of D. metel with different solvents (hexane, chloroform, acetone, and methanol) showed antifungal activity against three Aspergillus species: A. fumigatus, A. niger and A. flavus, where the minimum inhibitory concentration (MIC) of chloroform fraction was $625.0 \mu \mathrm{g} / \mathrm{mL}$ [83].

The antifungal activity of methanol extracts from the leaves, seeds, stems and roots of $D$. inoxia was evaluated by determining the growth inhibition of five fungal species: A. flavus, A. niger, Alternaria solani, Fusarium solani and Helianthus sporium [84].

The antifungal activity of $D$. stramonium extracts on Candida albicans showed higher growth inhibition rates in aqueous extracts $(74 \%)$, although with good inhibitory activities of methanol and chloroform extracts $(69 \%$ and $65 \%$, respectively) [19].

\section{Antibacterial activity}

Leaf and fruit extracts of $D$. stramonium with solvents of different polarity were evaluated against 5 pathogenic microorganisms where the extracted methanol and chloroform fractions from both leaves and fruits showed growth inhibition of all tested microorganisms at different concentrations. Growth of Pseudomonas aeruginosa and Klebsiella pneumonia was effectively reduced by all extracted fractions from the fruits. The maximum growth reduction $(77 \%)$ was presented by the chloroform extract of leaves against $K$. pneumonia [19].

Antibiotic activity of methanolic extracts (80\%) of Datura inoxia against Bacillus subtilis, Staphylococcus aureus, Escherichia coli by paper disk diffusion method using ampicillin as a positive control. The results indicated activity against all bacteria at the highest concentration of the extracts except $E$. coli. $(2.5 \mu \mathrm{g} / \mathrm{mL})$ [85]. Similarly, ethanolic and methanolic extracts from leaves and fruits of Datura metel, respectively, were tested as antibiotics against $S$. aureus, $P$. aeruginosa, $P$. mirabilis, E. coli, $K$. pneumoniae, resulting in growth inhibition against all bacteria species except $E$. coli [43], [62], [73].

On the other hand, methanolic, ethanolic and aqueous extracts of $D$. stramonium have shown antibacterial activities against gram-positive and gramnegative bacterial in paper disk diffusion method [64]. Ethanolic extract of leaves inhibited the growth of bacteria for P. aeruginosa, K. pneumoniae and E. coli with $25 \% \mathrm{w} / \mathrm{v}$ as the minimum inhibitory concentration [86]. The methanolic leaf extract demonstrated antibacterial activity against gram-positive bacteria Staphylococcus haemolyticus, S. aureus, Shigella dysenteriae, Bacillus cereus, and against gram-negative bacteria, such as: $P$. aeruginosa, $K$. pneumoniae and E. coli at $2.5,1.25$ and $0.75 \mathrm{mg} / \mathrm{mL}$ [42], [64], [85], [87], [88].

\section{Antioxidant activity}

Aqueous extracts of $D$. metel stems, roots and leaves presented between 23.8 and $49.3 \%$ antioxidant activity [62]. Methanolic extract of D. stramonium presented values of IC50 for radical DPPH, superoxide, and radical cation ABTS of $35.3,10.5$ and $49.36 \mu \mathrm{g} / \mathrm{mL}$, respectively [20]. In D. innoxia the antioxidant capacity and concentration of phenolic compounds and flavonoids in addition to the higher antioxidant capacity $(221.25 \pm 1.06 \mathrm{mg} \mathrm{EPA} / \mathrm{g})$ was evaluated in comparison to $D$. metel reaching significantly higher values than the latter in all determinations [89]. D. metel leaf methanol extract showed the highest antioxidant capacity in a DPPH purification test against other solvents and plant organs mainly due to the presence of the highest number of phenolic compounds, including flavonoids and tannins [90].

\section{Hypoglycemic activity}

The hypoglycemic activity of $D$. metel seeds were studied by adding ground seeds to the diet of rats with induced diabetes finding a significant reduction in blood glucose levels after 8 hours of its administration [91]. Hydromethanolic extract of $D$. stramonium root was evaluated in diabetic mice not showing significant hypoglycemic activity in the mice, although at relatively high doses $(100,200$ and $400 \mathrm{mg} / \mathrm{kg})$, the extract significantly reduced blood glucose levels in diabetic by orally loaded mice [92]. D. inoxia methanolic leaf extract showed inhibitory effect on $\alpha$-glucosidase, $\alpha$-amylase, lipase, and urease indicating antihyperglycemic effects [93]. 


\section{Cytotoxic activity}

The ethyl acetate fraction of the ethanolic extract of $D$. metel flowers was studied against cancer cell lines, showing cytotoxicity activity against A549 was observed, reaching $66.84 \%$ at $599 \mathrm{ug} / \mathrm{mL}$ [20]. These results were like those exposed by Gupta et al. [95] where the cytotoxic effects of methanolic extracts of D. stramonium leaves against A549 and MCF7 were evaluated, presenting a significant immunostimulation [94]. D. innoxia methanolic leaf extract showed a potential cytotoxic effect on MCF-7 cell lines of human breast cancer with an $\mathrm{IC}_{50}$ of $93.73 \mu \mathrm{g} / \mathrm{ml}[94]$.

A phytosterol was identified and isolated from D. inoxia leaf extracts, Rhinoxia B, which showed antiproliferative activity against human colon adenocarcinoma cells, HCT 15 with an IC50 value of $4 \mu \mathrm{M}$ [95]

\section{OTHER ACTIVITIES}

The presence of tropane alkaloids gives to the genus Datura anticholinergic (mydriatic, antispasmodic), anesthetic, analgesic, sedative-hypnotic, antiparkinsonian, and aphrodisiac properties [13]. This activities in tropane alkaloids are associated to a competitive antagonist of muscarinic receptors [66]. however, some tropane alkaloids and their derivatives have shown different affinities to nicotinic acetylcholine receptor, although to a lesser extent, being in some cases a partial agonist [96]-[99].

The effects of tropane alkaloids on the nervous system are also related to the activity of monoaminergic neurotransmitters, where tropane alkaloids have different levels of affinity with monoaminergic transporters [100]-[102].

\section{CONCLUSION}

Species of the genus Datura are one of the oldest plants known used in traditional medicine. Its psychotropic effects have made it a source of important cultural traditions. Based on this cultural knowledge, the effects of plants of the genus have been evaluated in different general biological activities, such as: insecticide, fungicide and antibacterial, among others. Moreover, the study of plant components has led to studies on more important biological activities such as cytotoxicity in cancer cells. The importance of studies of secondary metabolites of the genus Datura has led to important discoveries regarding its biological activities. However, new studies continue to discover new metabolites with potential biological activity at different systems that made the genus as an important source of compounds with interesting pharmacological applications.

\section{REFERENCES}

1. Olmstead, R. G., Bohs, L., Migid, H. A., Santiago-Valentin, E., Garcia, V. F., \& Collier, S. M. (2008). A molecular phylogeny of the Solanaceae. Taxon, 57(4), 1159-1181.

2. Olmstead, R. G. (2013). Phylogeny and biogeography in Solanaceae, Verbenaceae and Bignoniaceae: a comparison of continental and intercontinental diversification patterns. Botanical Journal of the Linnean Society, 171(1), 80-102.

3. De Jesus Matias, L., Rocha, J. A., de Andrade Royo, V., Menezes, E. V., de Melo Júnior, A. F., \& de Oliveira, D. A. (2019). Phytochemistry in medicinal species of Solanum L. (Solanaceae). Pharmacognosy Research, 11(1), 47.

4. Dupin, J., Matzke, N. J., Särkinen, T., Knapp, S., Olmstead, R. G., Bohs, L., \& Smith, S. D. (2017). Bayesian estimation of the global biogeographical history of the Solanaceae. Journal of Biogeography, 44(4), 887-899.

5. Chowański, S., Adamski, Z., Marciniak, P., Rosiński, G., Büyükgüzel, E., Büyükgüzel, K. \& Bufo, S. A. (2016). A review of bioinsecticidal activity of Solanaceae alkaloids. Toxins, 8(3), 60 .

6. Ibrahim, M., Siddique, S., Rehman, K., Husnain, M., Hussain, A., Akash, M. S. H., \& Azam, F. (2018). Comprehensive analysis of phytochemical constituents and ethnopharmacological investigation of genus Datura. Critical Reviews ${ }^{\mathrm{TM}}$ in Eukaryotic Gene Expression, 28(3).

7. Palazón, J., Moyano, E., Bonfill, M., Cusidó, R. M., Piñol, M. T., \& da Silva, J. T. (2006). Tropane alkaloids in plants and genetic engineering of their biosynthesis. Floriculture, Ornamental and Plant Biotechnology, II, 209 221.

8. Nayyar, M. S., Hanif, M. A., Mjaeed, M. I., Ayub, M. A., \& Rehman, R. (2020). Datura. In Medicinal Plants of South Asia (pp. 207-216). Elsevier.

9. Benítez, G., March-Salas, M., Villa-Kamel, A., Cháves-Jiménez, U., Hernández, J., Montes-Osuna, N., \& Cariñanos, P. (2018). The genus Datura L. (Solanaceae) in Mexico and Spain-Ethnobotanical perspective at the (tongue), BGC-823 (gastric) and K562 (leukemia) [53]. Likewise, cytotoxicity of methanolic extracts of Datura stramonium seed against MCF7 (breast cancer)

interface of medical and illicit uses. Journal of ethnopharmacology, 219 , 133-151.

10. King, A., Powis, T. G., Cheong, K. F., Deere, B., Pickering, R. B., Singleton E., \& Gaikwad, N. W. (2018). Absorbed residue evidence for prehistoric Datura use in the American Southeast and Western Mexico. Advances in Archaeological Practice, 6(4), 312-327.

11. Valenzuela, E. (2011). Three notes on the use of medicinal plants in curative and bewitchment rituals (Chile S.xviii). Intus-Legere Historia, 5(2), 89-105.

12. Al-Snafi, A. E. (2017). Medical importance of Datura fastuosa (syn: Datura metel) and Datura stramonium-A review. IOSR Journal of Pharmacy, 7(2), 43-58.

13. Carpa, R., Dumitru, D. V., Burtescu, R. F., Maior, M. C., Dobrotă, C., \& Olah, N. K. (2017). Bio-chemical analysis of Datura stramonium extract. Studia Universitatis Babes-Bolyai, Biologia, 62(2).

14. Anju, D., \& Ratan, L. (2011). Phytochemical and pharmacological status of Datura fastuosa Linn. Int J Res Ayurveda Pharm, 2(1), 145-150.

15. Bandhoria, P., Gupta, V. K., Sharma, V. K., Satti, N. K., Dutt, P., \& Suri, K. A. (2006). Crystal Structure of $6 \alpha, 7 \alpha$ : $24 \alpha, 25 \alpha$-Diepoxy-5 $\alpha, 12 \alpha$-dihydroxy1-oxo-20S, 22R-witha-2-enolide isolated from Datura quercifolia Leaves. Analytical Sciences: X-ray Structure Analysis Online, 22, x169$\mathrm{x} 170$.

16. Ali, M., Nishad, U., \& Yadav, V. K. (2020). Evaluation of phytochemical \& antibacterial activity on some Indian medicinal plants (Kateli, Datura, Makoi). Journal of Pharmacognosy and Phytochemistry, 9(2), 51-60.

17. Zheng, X. F., Li, C. X., Lu, H., \& Ren, C. H. (2007). Influence of alkaloid extracts from Datura stramonium L. on germination of several plant seeds. Seed, 4, 1-4.

18. Chamani, E., Rezaei, Z., Dastjerdi, K., Javanshir, S., Khorsandi, K., \& Mohammadi, G. A. (2019). Evaluation of some genes and proteins involved in Apoptosis on human chronic myeloid leukemia cells (K562 cells) by Datura innoxia Leaves Aqueous Extract. Journal of Biomolecular Structure and Dynamics, 1-12.

19. Bakht, J., Qureshi, M., Iqbal, A., \& Shafi, M. (2019). Effect of different solvent extracted samples from the leaves and fruits of Datura stramonium on the growth of bacteria and fungi. Pakistan journal of pharmaceutical sciences, 32(1).

20. Iqbal, S., Sivaraj, C., \& Gunasekaran, K. (2017). antioxidant and anticancer activities of methanol extract of seeds of Datura stramonium 1. Free Radicals \& Antioxidants, 7(2)

21. Khan, W., Subhan, S., Shams, D. F., Afridi, S. G., Ullah, R., Shahat, A. A., \& Alqahtani, A. S. (2019). Antioxidant potential, phytochemicals composition, and metal contents of Datura alba.BioMed research international, 2019

22. Mai, N. T., Cuc, N. T., Anh, H. L. T., Nhiem, N. X., Tai, B. H., Yen, P. H., $\&$ Oh, H. (2017). Two new guaiane sesquiterpenes from Datura metel L. with anti-inflammatory activity. Phytochemistry Letters, 19, 231-236.

23. Javid, M., Aziz, A., Azhar, M. F., \& Qayyum, A. (2017). Antioxidant, Antibacterial, Phytochemical Composition of Leaves and Roots Extracts of Datura alba. Zeitschrift Fur Arznei-\& Gewurzpflanzen, 22(4), 165-168.

24. Luna-Cavazos, M., Bye, R., \& Jiao, M. (2009). The origin of Datura metel (Solanaceae): genetic and phylogenetic evidence. Genetic resources and crop evolution, 56(2), 263

25. Setshogo, M. P. (2015). A review of some medicinal and or hallucinogenic Solanaceous plants of Botswana: the genus Datura L. Int. J. Appl. Res. Nat Prod, 1, 15-23.

26. Bye, R., Mata, R., \& Pimentel, J. (1991). Botany, ethnobotany, and chemistry of Datura lanosa (Solanaceae) in Mexico. Anales del Instituto de Biología. Serie Botánica, 61(1), 21-42.

27. Martínez, M., Vargas-Ponce, O., Rodríguez, A., Chiang, F., \& Ocegueda, S. (2017). Solanceae family in Mexico. Botanical Sciences, 95(1), 131-145.

28. Haegi, L. (1976). Taxonomic account of Datura L. (Solanaceae) in Australia with a note on Brugmansia Pers. Australian Journal of Botany, 24(3), 415435.

29. Rabei, S., Khedr, A., \& El Gamal, I. (2019). Clinopodium serpyllifolium subsp. barbatum (Lamiaceae) and Datura ferox (Solanaceae): New records for the flora of Egypt. Egyptian Journal of Botany, 59(1), 233-239.

30. Griffin, W. J., \& Lin, G. D. (2000). Chemotaxonomy and geographica distribution of tropane alkaloids. Phytochemistry, 53(6), 623-637.

31. Castillo, G., Calahorra-Oliart, A., Núñez-Farfán, J., Valverde, P. L., Arroyo, J., Cruz, L. L., \& Tapia-López, R. (2019). Selection on tropane alkaloids in 
native and non-native populations of Datura stramonium. Ecology and Evolution, 9(18), 10176-10184.

32. Dupraz, J. M., Christen, P., \& Kapetanidis, I. (1994). Tropane alkaloids in transformed roots of Datura quercifolia. Planta medica, 60(2), 158-162.

35. Tan, J., Liu, Y., Cheng, Y., Sun, Y., Pan, J., Guan, W., \& Kuang, H. (2020). New withanolides with anti-inflammatory activity from the leaves of Datura metel L. Bioorganic Chemistry, 95, 103541.

36. Liu, Y., Guan, W., Yang, C. L., Luo, Y. M., Liu, Y., Zhou, Y. Y.,\& Kuang, H. X. (2020). Steroids with potential anti-inflammatory activity from the roots of Datura metel L. Canadian Journal of Chemistry, 98(2), 74-78.

37. Kumral, N. A., Çobanoğlu, S., \& Yalcin, C. (2010). Acaricidal, repellent and oviposition deterrent activities of Datura stramonium L. against adult Tetranychus urticae (Koch). Journal of Pest Science, 83(2), 173-180.

38. Kuganathan, N., \& Ganeshalingam, S. (2011). Chemical analysis of Datura metel leaves and investigation of the acute toxicity on grasshoppers and red ants. Journal of Chemistry, 8(1), 107-112.

39. Jain, M., Muthukumaran, J., \& Singh, A. K. (2020). Structural and functional characterization of chitin binding lectin from Datura stramonium: insights from phylogenetic analysis, protein structure prediction, molecular docking and molecular dynamics simulation. Journal of Biomolecular Structure and Dynamics, 1-19.

40. Carlini, C. R., \& Grossi-de-Sá, M. F. (2002). Plant toxic proteins with insecticidal properties. A review on their potentialities as bioinsecticides. Toxicon, 40(11), 1515-1539.

41. Kilpatrick, D. C., \& Yeoman, M. M. (1978). Purification of the lectin from Datura stramonium. Biochemical Journal, 175(3), 1151-1153.

42. Gupta, A. K., Ahirwar, N. K., Shinde, N., Choudhary, M., Rajput, Y. S., \& Singh, A. (2013). Phytochemical screening and antimicrobial assessment of leaves of Adhatoda vasica, Azadirachta indica and Datura stramonium. UK Journal of Pharmaceutical and Biosciences, 1(1), 42-47.

43. Hossain, M. A., Al Kalbani, M. S. A., Al Farsi, S. A. J., Weli, A. M., \& AlRiyami, Q. (2014). Comparative study of total phenolics, flavonoids contents and evaluation of antioxidant and antimicrobial activities of different polarities fruits crude extracts of Datura metel L. Asian Pacific Journal of Tropical Disease, 4(5), 378-383.

44. Jasso, C., Nieto-Camacho, A., Ramírez-Apan, M., Martínez, M., \& Maldonado, E. (2020). Antioxidant, cytotoxic, and acetylcholinesterase inhibitory activities of withanolides from Datura quercifolia. Planta Medica International Open, 7(02), e68-e72.

45. Li, T., Wei, Z., Sun, Y., Wang, Q., \& Kuang, H. (2019). Withanolides, Extracted from Datura Metel L. Inhibit Keratinocyte Proliferation and Imiquimod-Induced Psoriasis-Like Dermatitis via the STAT3/P38/ERK1/2 Pathway. Molecules, 24(14), 2596.

46. Kagale, S., Marimuthu, T., Thayumanavan, B., Nandakumar, R., \& Samiyappan, R. (2004). Antimicrobial activity and induction of systemic resistance in rice by leaf extract of Datura metel against Rhizoctonia solani and Xanthomonas oryzae pv. oryzae. Physiological and Molecular Plant Pathology, 65(2), 91-100.

47. Aboluwodi, A. S., Avoseh, N. O., Lawal, A. O., Ogunwande, I. A., \& Giwa, A. A. (2017). Chemical constituents and antiinflammatory activity of essential oils of Datura stramonium L. J. Med. Plant Stud, 5(1), 21-25.

48. Hare, J. D., \& Sun, J. J. (2011). Production of induced volatiles by Datura wrightii in response to damage by insects: effect of herbivore species and time. Journal of chemical ecology, 37(7), 751-764.

49. Hare, J. D. (2007). Variation in herbivore and methyl jasmonate-induced volatiles among genetic lines of Datura wrightii. Journal of chemical ecology, 33(11), 2028-2043.

50. Yang, B. Y., Zhou, Y. Q., Liu, Y., Lu, Z. K., \& Kuang, H. X. (2018). Entkaurane diterpenoids from the pericarps of Datura metel L. acted on the

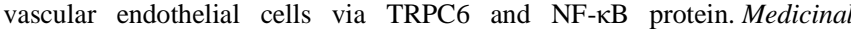
Chemistry Research, 27(1), 115-121.

51. Liu, Y., Guan, W., Lu, Z. K., Guo, R., Xia, Y. G., Lv, S. W., Yang, B. Y, \& Kuang, H. X. (2019). New sesquiterpenoids from the stems of Datura metel L. Fitoterapia, 134, 417-421.

52. Benabderrahim, M. A., Sarikurkcu, C., Elfalleh, W., \& Ozer, M. S. (2019). Datura innoxia and Dipsacus laciniatus: Biological activity and phenolic composition. Biocatalysis and Agricultural Biotechnology, 19, 101163.

53. Pan, Y., Wang, X., \& Hu, X. (2007). Cytotoxic withanolides from the flowers of Datura metel. Journal of natural products, 70(7), 1127-1132.

54. Veleiro, A. S., Cirigliano, A. M., Oberti, J. C., \& Burton, G. (1999). $7-$ Hydroxywithanolides from Datura ferox. Journal of natural products, 62(7), 1010-1012.
33. Nain, J., Bhatt, S., Dhyani, S., \& Joshi, N. (2013). Phytochemical screening of secondary metabolites of Datura stramonium. International Journal of Current Pharmaceutical Research, 5(2), 151-153.

34. Anulika, N. P., Ignatius, E. O., Raymond, E. S., Osasere, O., \& Hilda, A. (2016). The chemistry of natural product. Plant Secondary Metabolites, 4(August), 0-8.

55. Crowley, J. F., \& Goldstein, I. J. (1981). Datura stramonium lectin: isolation and characterization of the homogeneous lectin. FEBS Letters, 130(1), 149152.

56. Maheshwari, N. O., Khan, A., \& Chopade, B. A. (2013). Rediscovering the medicinal properties of Datura sp.: A review. Journal of medicinal plants Research, 7(39), 2885-2897.

57. Friedman, M., \& Levin, C. E. (1989). Composition of jimson weed (Datura stramonium) seeds. Journal of agricultural and food chemistry, 37(4), 9981005 .

58. Crowley, J. F., Goldstein, I. J., Arnarp, J., \& Lönngren, J. (1984) Carbohydrate binding studies on the lectin from Datura stramonium seeds. Archives of biochemistry and biophysics, 231(2), 524-533.

59. Desai, N. N., Allen, A. K., \& Neuberger, A. (1981). Some properties of the lectin from Datura stramonium (thorn-apple) and the nature of its glycoprotein linkages. Biochemical Journal, 197(2), 345-353.

60. Sasaki, T., Yamazaki, K., Yamori, T., \& Endo, T. (2002). Inhibition of proliferation and induction of differentiation of glioma cells with Datura stramonium agglutinin. British Journal of Cancer, 87(8), 918-923.

61. Ali, A., Ahmad, F., Biondi, A., Wang, Y., \& Desneux, N. (2012). Potential for using Datura alba leaf extracts against two major stored grain pests, the khapra beetle Trogoderma granarium and the rice weevil Sitophillus oryzae. Journal of Pest Science, 85(3), 359-366.

62. Monira, K. M., \& Munan, S. M. (2012). Review on Datura metel: A potential medicinal plant. Global Journal of Research on Medicinal Plants \& Indigenous Medicine, 1(4), 123.

63. Miraldi, E., Masti, A., Ferri, S., \& Comparini, I. B. (2001). Distribution of hyoscyamine and scopolamine in Datura stramonium. Fitoterapia, 72(6), 644-648.

64. Welegergs, G. G., Hulif, K., Mulaw, S., Gebretsadik, H., Tekluu, B., \& Temesgen, A. (2015). Isolation, structural elucidation and bioactivity studies of tropane derivatives of alkaloids from seeds extract of Datura stramonium. Science Journal of Chemistry, 3(5), 78-83.

65. El Bazaoui, A., Bellimam, M. A., \& Soulaymani, A. (2011). Nine new tropane alkaloids from Datura stramonium L. identified by GC/MS. Fitoterapia, 82(2), 193-197.

66. De Simone, R., Margarucci, L., \& De Feo, V. (2008). Tropane alkaloids: an overview. Pharmacologyonline, 1, 70-89.

67. Berkov, S. (2003). Alkaloids of Datura ceratocaula. Zeitschrift für Naturforschung C, 58(7-8), 455-458.

68. Kovatsis, A., Flaskos, J., Nikolaidis, E., Kotsaki-Kovatsi, V. P., Papaioannou, N., \& Tsafaris, F. (1993). Toxicity study of the main alkaloids of Datura ferox in broilers. Food and chemical toxicology, 31(11), 841-845.

69. Padula, L. Z., Bandoni, A. L., Rondina, R. V. D., \& Coussio, J. D. (1976) Quantitative determination of total alkaloids and scopolamine in Datura ferox growing in Argentina. Planta medica, 29(04), 357-360

70. Evans, W. C., \& Stevenson, N. A. (1962). Studies on Datura leichhardtii muell. Ex benth. Part II. Alkaloidal Constituents. Journal of Pharmacy and Pharmacology, 14(S1), 107T-110T

71. Berkov, S., Zayed, R., \& Doncheva, T. (2006). Alkaloid patterns in some varieties of Datura stramonium. Fitoterapia, 77(3), 179-182.

72. Okwu, D. E., \& Igara, E. C. (2009). Isolation, characterization and antibacterial activity of alkaloid from Datura metel Linn leaves. African Journal of Pharmacy and Pharmacology, 3(5), 277-281.

73. Khan, A. A., Afzal, M., Raza, A. M., Khan, A. M., Iqbal, J., Tahir, H. M., \& Aqeel, M. A. (2013). Toxicity of botanicals and selective insecticides to Asian citrus psylla, Diaphorina citri K. (Homoptera: Psyllidae) in laboratory conditions. Jokull Journal, 63, 52-72.

74. Abbasipour, H., Mahmoudvand, M., Rastegar, F., \& Hosseinpour, M. H (2011). Bioactivities of jimsonweed extract, Datura stramonium L. (Solanaceae), against Tribolium castaneum (Coleoptera: Tenebrionidae). Turkish Journal of Agriculture and Forestry, 35(6), 623-629.

75. Pascual-Villalobos, M. J., \& Robledo, A. (1998). Screening for anti-insect activity in Mediterranean plants. Industrial crops and products, 8(3), 183194

76. Olofintoye, L. K., Simon-Oke, I. A., \& Omoregie, O. B. (2011). Larvicida properties of Datura stramonium (jimson weed) and Nicotiana tabaccum (tobacco) extracts against the larvae of (Anopheles and Culex) mosquitoes. African Research Review, 5(2). 
77. Van Dam, N. M., \& Hare, J. D. (1998). Biological activity of Datura wrightii glandular trichome exudate against Manduca sexta larvae. Journal of Chemical Ecology, 24(9), 1529-1549.

78. Ali, K., Shuaib, M., Ilyas, M., Hussain, F., Arif, M., Ali, S., \& Hussain, F. (2017). Efficacy of various botanical and chemical insecticides against flea beetles on maize (Zea maize L.). PSM Veterinary Research, 2(1), 6-9.

81. Ghosh, S., Tiwari, S. S., Srivastava, S., Sharma, A. K., Nagar, G., Kumar, K. A., Kumar, R., \& Rawat, A. K. S. (2015). In vitro acaricidal properties of Semecarpus anacardium fruit and Datura stramonium leaf extracts against acaricide susceptible (IVRI-I line) and resistant (IVRI-V line) Rhipicephalus (Boophilus) microplus. Vet. Sci. Res. J., 101, 69-74.

82. Shyma, K. P., Gupta, J. P., Ghosh, S., Patel, K. K., \& Singh, V. (2014). Acaricidal effect of herbal extracts against cattle tick Rhipicephalus (Boophilus) microplus using in vitro studies. Parasitol. Res, 113(5), 19191926.

83. Sharma, G. L. (2002). Studies on antimycotic properties of Datura metel. Journal of ethnopharmacology, 80(2-3), 193-197.

84. Kalim, M., Hussain, F., Ali, H., Ahmad, I., \& Iqbal, M. N. (2016). Antifungal activities of methanolic extracts of Datura inoxia.PSM Biological Research, 1(2), 70-73.

85. Eftekhar, F., Yousefzadi, M., \& Tafakori, V. (2005). Antimicrobial activity of Datura innoxia and Datura stramonium. Fitoterapia, 76(1), 118-120.

86. Banso, A., \& Adeyemo, S. (2006). Phytochemical screening and antimicrobial assessment of Abutilon mauritianum, Bacopa monnifera and Datura stramonium. Biokemistri, 18(1).

87. Reddy, B. U. (2009). Antimicrobial activity of Datura stramonium L. and Tylophora indica (Burm. f.) Merr. Pharmacologyonline, 1, 1293-1300.

88. Altameme, H. J., Hameed, I. H., \& Kareem, M. A. (2015). Analysis of alkaloid phytochemical compounds in the ethanolic extract of Datura stramonium and evaluation of antimicrobial activity. African Journal of Biotechnology, 14(19), 1668-1674.

89. Bhardwaj, K., Kumar, S., \& Ojha, S. (2016). Antioxidant activity and FT-IR analysis of Datura innoxia and Datura metel leaf and seed methanolic extracts. African Journal of Traditional, Complementary and Alternative Medicines, 13(5), 7-16.

90. Alabri, T. H. A., Al Musalami, A. H. S., Hossain, M. A., Weli, A. M., \& AlRiyami, Q. (2014). Comparative study of phytochemical screening, antioxidant and antimicrobial capacities of fresh and dry leaves crude plant extracts of Datura metel L. Journal of King Saud University-Science, 26(3), 237-243.

91. Murthy, B. K., Nammi, S., Kota, M. K., Rao, R. K., Rao, N. K., \& Annapurna, A. (2004). Evaluation of hypoglycemic and antihyperglycemic effects of Datura metel (Linn.) seeds in normal and alloxan-induced diabetic rats. Journal of ethnopharmacology, 91(1), 95-98.

92. Belayneh, Y. M., Birhanu, Z., Birru, E. M., \& Getenet, G. (2019). Evaluation of in vivo antidiabetic, antidyslipidemic, and in vitro antioxidant activities of hydromethanolic root extract of Datura stramonium L. (Solanaceae). Journal of experimental Pharmacology, 11, 29.
79. Javaid, A., Shafique, S., \& Shafique, S. (2008). Herbicidal activity of Datura metel L. against Phalaris minor Retz. Pak. J. Weed Sci. Res, 14(3-4), 209220 .

80. Sakadzo, N., Pahla, I., Muzemu, S., Mandumbu, R., \& Makaza, K. (2018). Herbicidal effects of Datura stramonium (L.) leaf extracts on Amaranthus hybridus (L.) and Tagetes minuta (L.). Afr. J. Agric. Res., 13(34), 1754-1760.

93. Bagewadi, Z. K., Muddapur, U. M., Madiwal, S. S., Mulla, S. I., \& Khan, A. (2019). Biochemical and enzyme inhibitory attributes of methanolic leaf extract of Datura inoxia Mill. Environmental Sustainability, 2(1), 75-87.

94. Gupta, A., Kumar, S., Mahindroo, N., \& Saini, R. V. (2016). Bioactive fraction from Datura stramonium Linn. promotes human immune cells mediated cytotoxicity towards lung and breast cancer cells. Pharmacognosy Journal, 8(5).

95. Gajendran, B., Durai, P., Varier, K. M., \& Chinnasamy, A. (2020). A novel phytosterol isolated from Datura inoxia, RinoxiaB is a potential cure colon cancer agent by targeting $\mathrm{BAX} / \mathrm{Bcl} 2$ pathway. Bioorganic \& Medicinal Chemistry, 28(2), 115242.

96. Pin, F., Vercouillie, J., Ouach, A., Mavel, S., Gulhan, Z., Chicheri, G. \& Suzenet, F. (2014). Design of $\alpha 7$ nicotinic acetylcholine receptor ligands in quinuclidine, tropane and quinazoline series. Chemistry, molecular modeling, radiochemistry, in vitro and in rats evaluations of a $\left[{ }^{18} \mathrm{~F}\right]$ quinuclidine derivative. European journal of medicinal chemistry, 82, 214224.

97. Carroll, F. I., Blough, B. E., Mascarella, S. W., Navarro, H. A., Eaton, J. B., Lukas, R. J., \& Damaj, M. I. (2010). Nicotinic acetylcholine receptor efficacy and pharmacological properties of 3 -(Substituted phenyl)-2 $\beta$-substituted tropanes. Journal of medicinal chemistry, 53(23), 8345-8353.

98. Papke, R. L., Schiff, H. C., Jack, B. A., \& Horenstein, N. A. (2005). Molecular dissection of tropisetron, an $\alpha 7$ nicotinic acetylcholine receptorselective partial agonist. Neuroscience letters, 378(3), 140-144.

99. Schmeller, T., Sporer, F., Sauerwein, M. \& Wink, M. (1995). Binding of tropane alcaloids to nicotinic and muscarinic acetylcholine receptors. Pharmazie, 50(7), 493-495.

100.Kirjavainen, A. K., Forsback, S., López-Picón, F. R., Marjamäki, P., Takkinen, J., Haaparanta-Solin, M., \& Solin, O. (2018). ${ }^{18}$ F-labeled norepinephrine transporter tracer $\left[{ }^{18} \mathrm{~F}\right]$ NS12137: radiosynthesis and preclinical evaluation. Nuclear medicine and biology, 56, 39-46.

101.Carroll, F. I., Gray, J. L., Abraham, P., Kuzemko, M. A., Lewin, A. H., Boja, J. W., \& Kuhar, M. J. (1993). 3-Aryl-2-(3'-substituted-1', 2', 4'-oxadiazol-5'yl) tropane analogs of cocaine: affinities at the cocaine binding site at the dopamine, serotonin, and norepinephrine transporters. Journal of medicinal chemistry, 36(20), 2886-289 